\title{
カメムシ類によるカキの被害と加害種の生態について
}

\author{
池田二三高*・福代 和久**
}

Fumitaka Ikeda and Kazuhisa Fukuyo: Damage of Japanese persimon attacked by several species of stink bug and their life histories.

摘要 : カメムシ類によるカキの被害が多いので, カキの被害実態, 加害種の種類と加害量の調査, 誘殺消 長調査, 寄主植物における発育各態の発生消長調査, 室内飼育などを行ない, 主要加書とその発生生態を明 らかにした。

カキの被害は，越冬後の成虫による被害も発生したが，9月以降，成熟期にかけて，主として新成虫が越 冬前に栄養撕取をするために生ずる被害の方が著しかった。加害種は 7 種が記録され，そのうち主要加害種 はチャバネアオカメムシ, ツヤアオカメムシの 2 種で, その他の種類による実害は軽微と推察された. 主要 種の 2 種は, 野外ではともにスギ，ヒノキを主な寄主植物として発生していることが明らかになり，チャバ ネアオカメムシでは年 2 世代, ツャアオカメムシでは年 1 政代の発生と推察された.

\section{I 。緒言}

カキを初めとする果樹類には, 古くからカメムシ類 による被害が知られているが，その発生は散発的，局 地的なことが多く, 本虫は重要害虫として取り上げら れてはいなかった.ところが, 静岡県において, 1971 年の秋に, 県西部地方で突然カメムシによるカキの被 害が多発して，大きな問題となり，この被害は翌年以 降も継続して発生したため, 防除対策が現地から強く 要望された. 本虫は全国的にも1973年に大発生をして 以来, 各県でカキを初めとする果樹類に多くの被害を もたらし, 重要害虫として注目されるようになった。

ここでは, 静岡農試落葉果樹試験地 (現静岡柑試落 葉果樹試験地, 浜松市都田町沢上) の䦛場およびその 周辺において，1971〜1975年の 5 力年間調查を行なっ た結果, カメムシ類によるカキの被害の実態と主要加 害種の発生生態について若干の知見を得た．まだ多く の未検討な点を残しているが，これまでに得た資料を まとめて関係者の参考に供したい.

本文に入るに先立ち, 文献の紹介, 各種カメムシ類 の生態について多くの御教示を戴いた東北農試の小林 尚博士, 静岡県島田市の井上智雄氏に厚くお礼を申し 上げる.

\section{II . カキの被害の発生時期}

\section{調查方法}

1972～1975年の 4 カ年間, $7 \sim 10$ 月にかけて試験地 甬場内のカキ（品種前川次郎）のうちから10樹を定め, 被害果数を随時調查した。

\section{結果および考察}

1972～1975年の調査によれば，力キの被害果発生消 長は第 1 図のとおりである.

1972 1974年の 3 力年は同様の発生型を示し， 8 月 上旬にわずかに被害が生じ，その後月末まで増加はな いが 9 月になると再び増加をはじめ，とくに 9 月中〜 下旬に集中する結果となったままた，10月上旬にはほ ぼ終了し, 成熟期の被害はほとんど発生しなかった。

1975年は，7月下旬～ 8 月上旬にかけて早期の被害 が前の 3 力年より多かったが，9月以降の被害は少な く 4 力年の調査のうちでは最も少ない被害量であった． このように静岡県では被害の発生時期は，7月下旬 〜 月上旬に現われる年と, 9 月以降に現われる年が あったが, 前者の被害よりむしろ後者における被害の 方が著しかった. 1975年 8 月上旬までの早期の被害は， 主としてチャバネアオカメムシの越冬個体によるもの と考えられ, 前年の多発生と越冬歩合の高かったこと や, 主要な発生源であるスギ, ヒノキの着救歩合がこ の年には低かったことが重なり，他の植物に対して成 虫の分散活動が高まったことも，大きな要因の一つと

\section{* 静岡県農業試験場 $* *$ 静岡県柑橘試験場}

* Shizuoka Agricultural Experiment Station, ** Shizuoka Citrous Experiment Station, Shizuoka, Japan.

1977. 1. 7. 受理 
して考えられる。また，9月以降の被害は，いずれの 年もチャバネアオカメムシ, ツヤアオカメムシが, 越 冬前の栄峑摂取植物として, 一時的に加害したものと 考えられる。

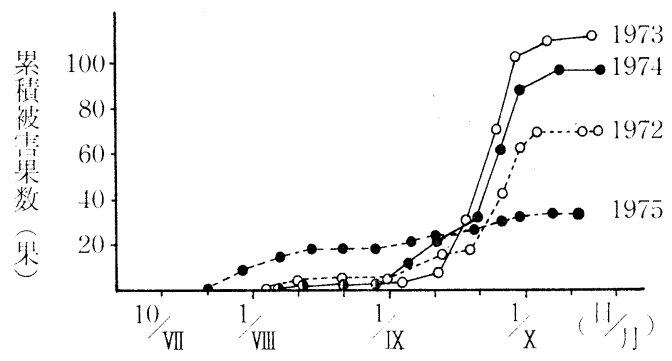

第 1 図 各年のカキ 10 樹当りの累積被害果消長

\section{III. カキを加害するカメムシの種類}

\section{調查方法}

1972〜1975年にかけ，場内團場および現地國場にお いて各種カメムシ類の加害を観察するとともに採集を 行なった。また,これらのカメムシは, 採集の都度カ キ果実と水を含ませた綿球を入れたプラスチック製容 器内で継続飼育し, 果実に吸収害を現わした種のみを 加害種とした。

\section{結果および考察}

甬場のカキ果害から採集したカメムシは, 第 1 表に 示すように12種であった．このうちクサギカメムシ， アオクサカメムシ, チャバネアオカメムシ， ツヤアオ カメムシ, セアカツノカメムシ, オオクモへリカメム シ, ホソヘリカメムシの 7 種が加害種として確認され

第 1 表 カキより採集したカメムシ類

加害を認めた種類

1. Halyomorpha brevis Walker クサギカメムシ

2. Nezara antenata Scott アオクサカメムシ

3. Plautia crossata Dallas チャバネアオカメムシ

4. Glaucias subpunctatus Walker ツヤアオカメムシ

5. Anacanthosoma denticauda Jakovlev

6. Anacanthocoris striicornis Scott セアカツノカメムシ

オオクモヘリカメムシ

7. Riptortus clavatus Thunberg ホソヘリカメムシ 加害を認めなかった種類

1. Piezodorus hybneri Gmelin イチモンジカメムシ

2. Cletus trigonus Thunberg ホソハリカメムシ

3. Leptocorixa corbetti China クモヘリカメムシ

4. Physopelta gutta Burmeister 才才ホシカメムシ

5. Physopelta cincticollis Stål ヒメホシカメムシ
た.これらの 7 種は果樹の加害種としての歴史が古く, すでに昭和初期までに全国各地で各種の果樹に対して 被害を与えた種として報告1)されており，七アカッ, カメムシを除く 6 種は, 1973年の全国的な大発生の折 に，他県でも各種の果樹に被害を与えている1). また， 福岡県では, カキを初めとする果樹類に1960年以降, チャバネアオカメムシ，ツヤアオカメムシの被害の多 いことが報告されている7,11).

川沢ら4) が整理してまとめたカメムシ類の寄主植物 は, これらの加害種ではクサギカメムシで21科48種, アオクサカメムシで 5 科 83 種, ツャアオカメムシで 12 科17種, チャバネアオカメムシで 30 科 55 種, セアカツ ノカメムシで 8 科 10 種, オオクモへリカメムシで 5 科 27種である. さらに宮原ら ${ }^{8,99}$ は, このほかの植物とし てッャアオカメムシに 7 科 8 種, チャバネアオカメム シに26科39種を追加している．筆者らはこのほかにチ ヤバネアオカメムシがクサギ（クマツヅラ科），エビ ヅル (ブドウ科)，ツヤアオカメムシがクロマツ（マ ツ科), セアカツノカメムシがナツハゼ（スオウ科）. を吸収加害するのを確認しているが, 今後の調査でさ らに追加されるであろう。

このように各加害種とも非常に雑食性であるが，こ れらの植物のほとんどは成虫が一時期に吸収加害する 植物であって，幼虫が生育できる植物は非常に少ない， カキではいずれの加害種の幼虫も完全に生育できない ので, 成虫が一時的に栄養摂取をする植物になってい るといえよう.

\section{IV. 加害種の加害量}

\section{調査方法}

加害種 7 種の相対的な加害量を知るため, 各種の成 虫を各 5 頭プラスチック製容器に入れ, カキ果実 1 個 と水を含ませた綿球を与え室内で飼育した．果実は 2 日毎にかえ, 皮をむいて吸収加害孔数を調査して加害 量とした. 調査期間は, チャバネアオカメムシ, ツヤ アオカメムシ, セアカツノカメムシ, オオクモヘリカ メムシ，ホソヘリカメムシは1974年 9 月 10〜10月 3 日 までとした．クサギカメムシ，アオクサカメムシの 2 種は翌年の同期間に行なった．供試個体は野外で採集 した成虫を, 試験開始まで室内飼育しておいたものを 使用した，また，成虫が死亡した場合は，その都度新 しい個体を補給した。

\section{結果および考察}

この結果, 実験期間中の加害消長は第 2 図に示すと おりで，各種とも日による変動が大きかった：この期 


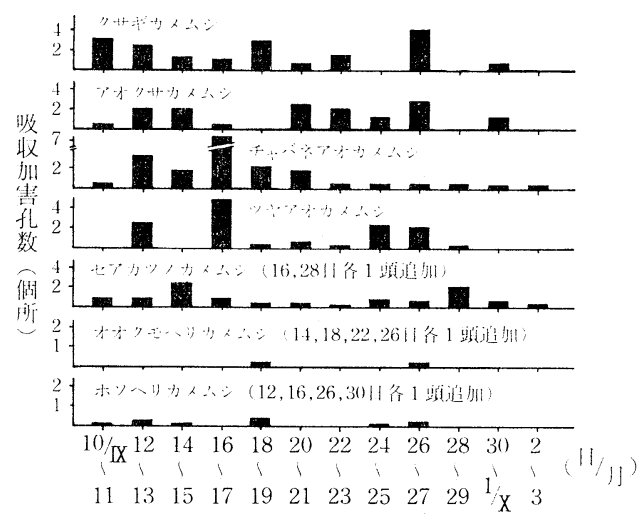

第 2 図 加害種 1 頭当りの 2 日間の平均加害量

間中の 1 日 1 頭当り平均吸収加害孔数は, チャバネア オカメムシ 0.8 力所, クサギカメムシ 0.7 カ所, ツヤア オカメムシ 0.5 カ所, セアカツノカメムシ 0.4 カ所, ア オクサカメムシ 0.3 カ所, ホソヘリカメムシ 0.1 カ所, オオクモヘリカメムシ 0 カ所であった.このうち, オ オクモヘリカメムシ，ホソヘリカメムシは室内試験の 加害量が非常に少ないことや, 試験中の死亡個体も多 かったことから，力キは成虫にとっても好適な提食対 象植物でないことがうかがえた。

\section{V. 主 要 加 害 種}

\section{調査方法}

カキに被害を与えている主要なカメムシの種類を知 るため, 被害の発生した1971〜1975年の 5 力年間, 誘 殺燈 (100W 高圧水銀燈, 乾式) による誘殺数, 力キ 10 樹当りの成虫の寄生数と被害果数, 室内試験の加害 量の調查結果などから検討を加え, 主要加害種を推定 した.

\section{結果および考察}

1971～1975年における各年の年間総誘殺数は第 2 表 に示すように, チャバネアオカメムシ, ツヤアオカメ

第 2 表 加害種の年間総誘殺数

\begin{tabular}{|c|c|c|c|c|c|}
\hline 名 & 1971 & 1972 & 1973 & 1974 & 1975 \\
\hline クサギカメムシ & 1 & 2 & 2 & 2 & 8 \\
\hline アオクサカメムシ & 553 & 464 & 445 & 444 & 168 \\
\hline チャバネアオカメムシ & 406 & 247 & 363 & 222 & 477 \\
\hline ツヤアオカメムシ & 439 & 193 & 1,204 & 269 & 412 \\
\hline セアカツノカメムシ & 0 & 0 & 2 & 4 & 7 \\
\hline オオクモいリカメハシ & 4 & 未調査 & 11 & 7 & 10 \\
\hline ホソヘリカメムシ & 127 & 未調査 & 158 & 60 & 85 \\
\hline
\end{tabular}

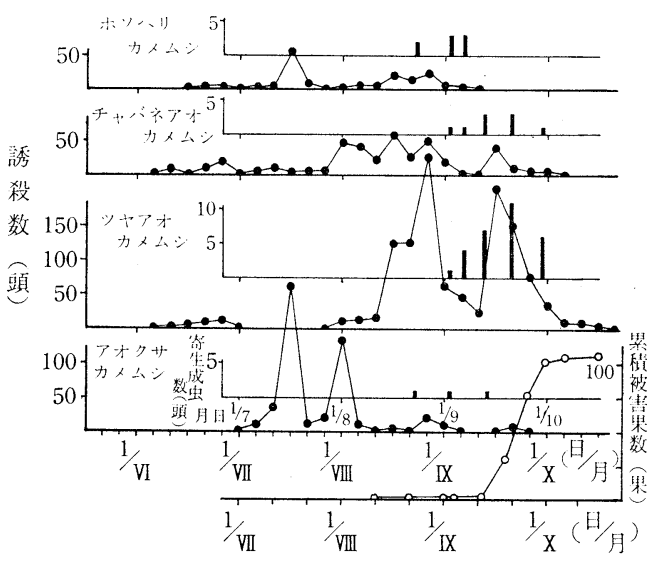

第 3 図 カメムシ類の誘殺消長 (1973) 10 樹当り寄生成虫数, 10 樹当り累積 被害数で表わす。 その他の加害種の誘殺数, 寄生数は 極く少数のため省略.

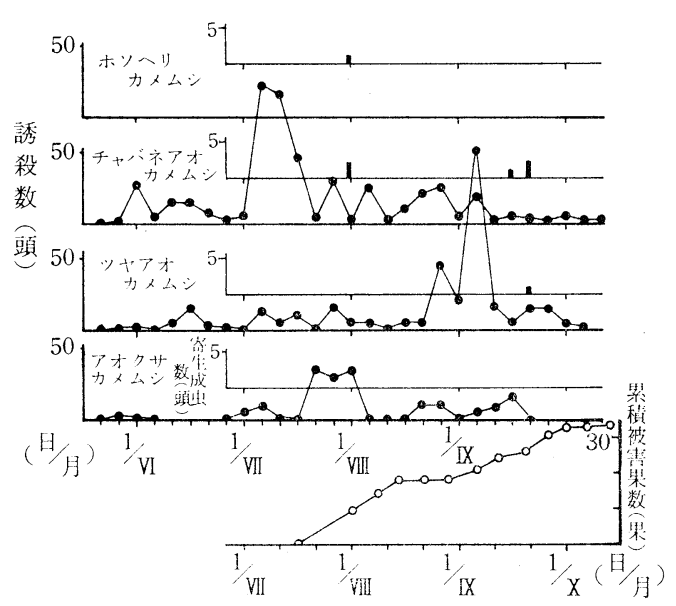

第 4 図 カメムシ類の誘殺消長 (1975) 10 樹当り寄生成虫数, 10 樹当り累積 被害果消長。

その他の加害種の誘殺数, 寄生数は 極く少数のため省略.

ムシ，アオクサカメムシ，ホソヘリカメムシの 4 種が 有意に多い種であった.

5 力年の調查で被害の最も多かった1973年の誘殺消 長, 被害果発生消長, 成虫の寄生消長は第 3 図のとお りである。この結果，カキの被害が増加する 9 月以降 に誘殺の多い種類は, チャバネアオカメムシ, ツャア オカメムシであり，両種は 9 月に扒けるカキ樹上の答 生虫数も多かった。1975年には第 4 図に示すように 7 月中旬〜8月中们に被暃が多く見られたが，この時期 にはほかの年には見られないはど多数のチャバッア才 カメムシの誘殺があった。また, 両種とも室内試験の 
加害量が多いので（第 2 図), チャバネアオカメムシ の 2 種が主要加害種と考えられる.

一方, 年間の総誘殺数 (第 2 表) の多いアオクサカ メムシは, 室内試験の加害量や $7 \sim 8$ 月の誘殺数が多 いことなど主要加害種と判断されやすいが, 野外では 誘殺最盛期の $7 〜 8$ 月にカキの被害は増加しないこと から，この間の加害量は極く少量にとどまっていると 推察され, 経済的に問題を引きおこす種類ではないと 考えられる。これは，カキに対するアオクサカメムシ の選択度が必ずしも高くないと推定されるほかに, 最 も好むイネ科やマメ科植物などの寄主植物が，この時 期には豊富に存在することも, 大きな要因の一つと考 えられる。

クサギカメムシ，七アカツノカメムシは室内試験の 加害量は非常に多かったが, 各年とも年間総誘殺数は 非常に少なく，したがって野外の発生も少ないと推定 され, 実害は軽微と考えられる.しかし, これら 2 種 類は県下では山間地に多く生息する種類であるため, 今後山間地のカキでは両種の発生に留意する必要があ ろう.

オオクモヘリカメムシは, 室内試験における加害量, 各年の年間総誘殺数ともに非常に少なく, 野外のカキ に対する実害は軽微と考えられる。

ホソヘリカメムシは, 室内試験の加害量は, オオク モヘリカメムシと同様に少なかった。 また, 誘殺数は かなり多かったが, アオクサカメムシと同様に誘殺最 盛期ごろでもカキの被害は増加しなかったので, その 実害は軽微と考えられる.

このように静岡県のカメムシによるカキの被害は, チャバネアオカメムン, ツヤアオカメムシの単独また は両種によって生じており, 近年, 西南暖地で各種の 果樹に被害を与えている主要加害種1)と同様である.

山田ら ${ }^{11)}$ は福岡県での主要加害種も両種によるもの とし, カキの被害はカメムシの発生ピークの遅早より, 誘殺量の多少と密接な関連があることを示唆し, とく に $7 \sim 8$ 月以後の誘殺数の多い年は, 被害の多くなる 可能性を指摘しているが, 筆者らの調査でもほぼ同様 の傾向を示した. しかし，1971年7月のチャバネアオ カメムシ, 1975年 9 月のツヤアオカメムシの多発生時 に見られるように, 誘殺量が多くても被害の増加に直 結しないこともあり，宮原ら 7 もこうした事例のある ことを報告しているが，この原因については十分に究 明されていない。主要加害種は, 年または時期により 代ることがあるので, 今後の主要加害種や被害の予測 にあたっては, 誘殺調査のほかに, 各加害種の発生環 境, とくに主要発生源となる寄主植物や, 成虫が一時
的に栄養摂取する植物との発生の関連性など，総合的 に検討をすることが必要であろう。

\section{VI. 主要加害種の発生生態}

野外における主要加害種の発生の実態を知ることは, カキに対する防除対策上からもきわめて重要なことで ある. 主要加害敇がチャバネアオカメムシ, ツヤアオ カメムシであることが明らかとなったので，これらの 寄主植物上における発生消長調査を行なった.

チャバネアオカメムシについては，これまで卵〜幼 虫の記載 ${ }^{5)}$, 飼育結果 ${ }^{10,12)}$, 誘殺消長調查 ${ }^{7,11)}$, 寄主植 物 $\left.{ }^{4}, 5,8,9\right)$ の報告はあるが, 野外における発生消長 ${ }^{3}$ に 関する資料はそしい，また，ツヤアオカメムシについ てはこれまで卯〜幼虫が未記載種であって, その生活 史に関する資料も少ない2,6). このように, 両種とも 幼虫期に関する報告が少なく，したがって野外におけ る発生実態も不明な点が多かった。

そこで，今回はとくに，ツヤアオカメムシとチャバ ネアオカメムシを重点に, 野外における発生消長につ いて検討を加えた.

\section{1. 誘殺灯による誘殺状況}

\section{調査方法}

$1971 \sim 1975$ 年の 5 力年間, 場内の誘殺燈（100W 高 圧水銀燈，乾式）に誘殺されたカメムシ類を調査した。

\section{結果および考察}

5 カ年のチャバネアオカメムシ, ツヤアオカメムシ の半旬別誘殺消長は第 5 図および第 6 図のとおりであ る. 両種のカメムシとも初誘殺が 5 月下旬ころより始 まり，10月下旬ごろ終息している。 また, カキの被害 は10月に入ると急激に減少し, 収穫期間中の被害はほ とんど進行しないこと（第1図）などから，10月下旬 には大多数の個体が越冬状態に入るものと考えられる.

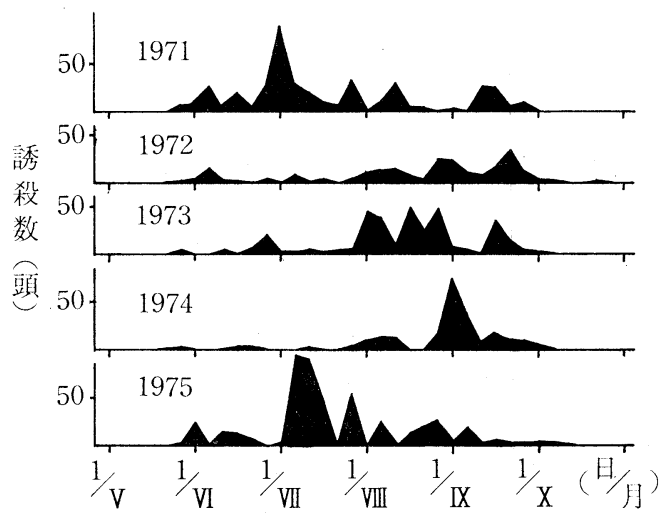

第 5 図各年のチャバネアオカメムシの誘殺消長 


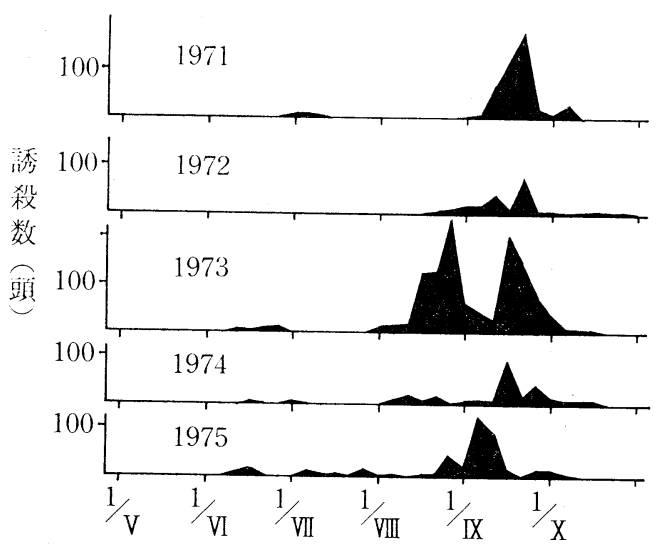

第 6 図 各年のツャアオカメムシの誘殺消長

ツヤアオカメムシは 5 カ年とも5〜 月月にかけては 少なく, 誘殺最盛期は $8 \sim 9$ 月にある傾向を示した. とくに1972年にはこの傾向は顕著で 8 月下旬以降の発 生は非常に多かったが， 8 月第 4 半旬までは合計 2 頭 の少数であった.

一方，チャバネアオカメムシはほぼ連続して誘殺さ れ，8〜9月に多くなる傾向を示したが，この時期が 必ずしも誘殺最盛期とはならず年により変動があった。 とくに1971〜1975年には，7月上忽が誘殺最盛期とな った.

各年の年間総誘殺数 (第 2 表) から, チャバネアオ カメムシの誘殺数は最多の年は最少の年の 2 倍であっ たが, ツヤアオカメムシのそれは約 6 倍となり, ツヤ アオカメムシの方が年次変動がはげしい種であるよう に思われた。

\section{2. 寄主植物上における発生消長}

\section{調査方法}

現地, 場内およびその周辺において, 各時期に寄主 植物上からチャバネアオカメムシ，シャアオカメムシ の発育各態を採集して, 年間の発生消長を調査した. 調査に当っては, 1973年は 9 月以降, 場内のナンキン 八ゼ 3 樹から各 1 枝, 1974年は 7 月以降, 現地（浜北 市大平) のカキ園の防風樹であるスギ, ヒノキの着球 樹をそれぞれ約15樹と，場内のナンキンハゼ10樹, 1975年は 6 月以降, 場内および周辺の防風樹であるス ギ, ヒノキの着戔樹10樹と, 場内のナンキンハゼ10樹 についてそれぞれ寄生数を調査した。

\section{結果および考察}

両種のスギ, ヒノキおよびナンキンハゼにおける発

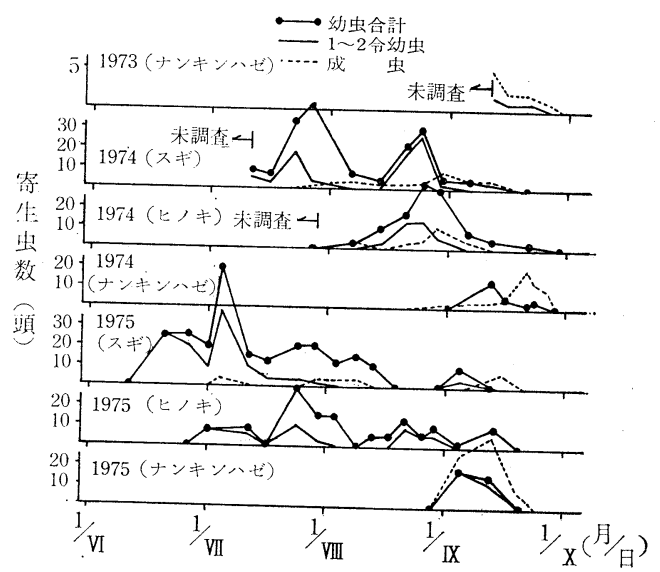

第 7 図 各寄主植物上に打けるチャバネアオカメ ムシの発生消長

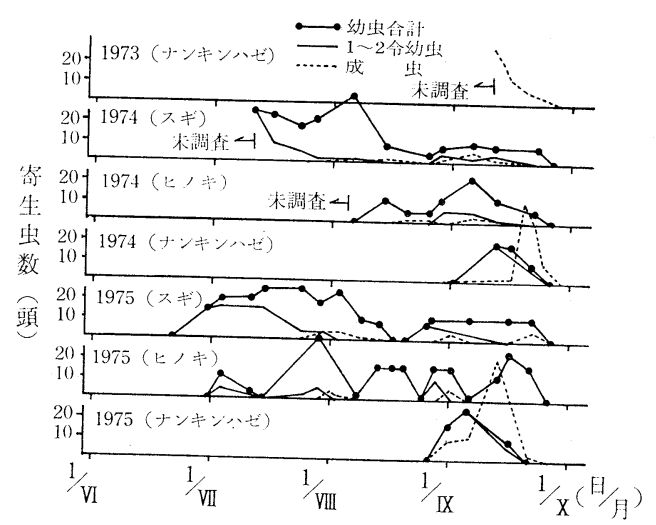

第 8 図 各寄主植物上に求けるッヤアオカメムシ の発生消長

生消長は, 第 7 図および第 8 図のとおりである.

このように，両種ともスギ，ヒノキに $6 \sim 9$ 月まで の長期間にわたって多数の発育各態が認められ, 幼虫 は完熟前のスギ，ヒノキの毝果を吸収加害して成虫に なることが認められ，これらが野外における主要な笴 主植物と考えられる.

ツヤアオカメムシでは，1 令幼虫は 6 月下旬〜 9 月 中旬までほぼ連続的に発生が認められたが，とくに7 月上〜中旬拉よび 8 月下旬〜 9 月下旬に多くなる傾向 を示した.

チャバネアオカメムシの発生消長も, ツヤアオカメ ムシとほぼ同様であった．また，1975年 5 月下旬の観 察では, ヤマグワの果害上では少数の 1 令幼虫が認め られたことや，小田ら年も5月にブドウ（ハウス栽培） やクワから卵や幼虫を採集しているので, チャバネア オカメムシの第 1 世代幼虫は, クワなどでは, スギ, 
ヒノキより約 1 力月早く発生するものと考えられる.

したがって, 越冬成虫の産卵は, ッャアオカメムシよ り早期に始まるものと考えられる。

スギ，ヒノキの述果は，9月下旬にはほぼ完熟する ので，カメムシにとっては加害が不適になるためか, 両種の幼虫および成虫の見られるのは，9月下旬まで である.また，スギ，ヒノキで 9 月以降に発生した 1 令幼虫は，この時期が種子の硬化〜完熟期に当ること や, 気温も次第に低下の時期に当たるため成虫への発 育は不可能と考えられる.

また，両種のカメムシの成虫は，8月からナンキン 八ゼ種子に飛来を始め，9月上〜中旬にかけてはとく に多くなる。しかし，種子の硬化とともに他への分散 を始め，9月下旬には全て姿を消す（第7 · 8 図）. ナンキンハゼに飛来する両種の一部には産卵を行なう 個体があって次世代幼虫が発生し，チャバネアオカメ ムシではその一部が成虫となるが，ツヤアオカメムシ では老令奻虫に至らず死亡する。また，チャバネアオ カメムシも 9 月以降に発生した 1 令奻虫は, スギ, ヒ ノキと同様の理由で成虫にはならないと考える.

このように主としてスギ，七ノキで発生した両種の 成虫は, 8 月下旬以降, 主要な発生源のスギ, ヒノキ 求果の硬化〜完熟につれて, 他の好適な植物を求めて 移動分散しているものと推察される。とくにこの時期 は越冬前の栄養搔食時期に当るため, 食害量も大きい
と推察され，摂食対象植物としてカキなどの果実，ナ ンキンハゼの種子などの選択度が, 非常に高いものと 考えられる。また，ナンキンハゼ上のカメムシ類の成 虫密度と, その後に現われるカキの被害量との関連性 は非常に高いものと推察されるが，その点は今後の検 討課題として残されている.

\section{3. 世代の経過数について}

\section{調查方法}

野外の寄主植物上に挑けるチャバネアオカメムシ， ツヤアオカメムシの発育各態の発生消長, 拉び誘殺 消長などの調査とともに, 年間の世代の経過数を明ら かにするために室内で飼育を行なった.

ツヤアオカメムシは，1974年に野外のスギから採集 した $1 \sim 3$ 令幼虫 25 頭と, これから羽化した第 1 回成 虫をそのまま越冬させて, 翌年産卵した 1 卯塊14卵を 用い，それぞれ第 1 世代の飼育を行なった。

第 2 世代はともに第 1 回成虫加ら採卵して，第 1 世 代と同様な方法で飼育を行なった。

飼育には腰高ぺトリ血を用い，スギ毢果を 2 日毎に 入れかえて室内で飼育した。越冬個体は，11月1日か ら翌年4日 1 日までは, 野外の百葉箱内において管理 された。

チャバネアオカメムシも，スギ，七ノキの述果より 採集した幼虫をツヤアオカメムシと同様の方法で飼育

第 3 表 ツヤアオカメムシ第 1 世代幼虫の飼育結果 (1974)

\begin{tabular}{|c|c|c|c|c|c|c|c|c|c|}
\hline \multirow{2}{*}{ 調査月日 } & \multirow{2}{*}{ 卵 } & \multicolumn{3}{|c|}{ 幼 } & \multicolumn{2}{|l|}{ 虫 } & \multirow{2}{*}{ 成虫 } & \multirow{2}{*}{ 合計 } & \multirow{2}{*}{ 備 } \\
\hline & & 1 令 & 2 令 & 3 令 & 4 令 & 5 令 & & & \\
\hline 7.15 & & 4 & 5 & 16 & & & & 25 & 野外のスギから採集 \\
\hline 17 & & & 3 & 8 & 12 & & & 23 & 1 令 3 令で各 1 頭死亡 \\
\hline 19 & & & 3 & 8 & 12 & & & 23 & \\
\hline 21 & & & 3 & 5 & 14 & & & 22 & 3 令で 1 頭死亡 \\
\hline 23 & & & & 5 & 7 & 10 & & 22 & \\
\hline 25 & & & & 3 & 5 & 13 & & 21 & 4 令で 1 頭死亡 \\
\hline 27 & & & & 3 & 4 & 12 & 2 & 21 & 第 1 回成虫発生 \\
\hline 29 & & & & & 5 & 6 & 8 & 19 & 5 令で 1 頭死亡 \\
\hline 31 & & & & & 3 & 6 & 10 & 19 & \\
\hline 8.2 & & & & & 3 & 4 & 10 & 17 & 5 令で 2 頭死亡 \\
\hline 4 & & & & & & 7 & 10 & 17 & \\
\hline 6 & & & & & & 5 & 12. & 17 & \\
\hline 8 & & & & & & 3 & 14 & 17 & \\
\hline 10 & & & & & & & 16 & 16 & 成虫で 1 頭死亡 \\
\hline
\end{tabular}

（註）第 1 回成虫のいずれかが，第 5 表の卵塊 $\mathrm{A} \sim \mathrm{E}$ を産卵.

第 1 回成虫のうち 5 頭（３，各 2 ）が，そのまま越冬完了. 
第 4 表 ツヤアオカメムシ第 1 世代奻虫の飼育結果（1975）

\begin{tabular}{|c|c|c|c|c|c|c|c|c|c|c|}
\hline \multirow{2}{*}{ 調査月日 } & \multirow{2}{*}{ 卵 } & \multicolumn{3}{|c|}{ 幼 } & \multicolumn{2}{|l|}{ 虫 } & \multirow{2}{*}{ 成虫 } & \multirow{2}{*}{ 合計 } & \multirow{2}{*}{ 偨 } & \\
\hline & & 1 令 & 2 令 & 3 令 & 4 令 & 5 令 & & & & \\
\hline 7.1 & 14 & & & & & & & 14 & 越冬成虫*より採卵， & 1 卵塊 \\
\hline 5 & & 14 & & & & & & 14 & & \\
\hline 7 & & 14 & & & & & & 14 & & \\
\hline 9 & & & 14 & & & & & 14 & & \\
\hline 11 & & & 14 & & & & & 14 & & \\
\hline 13 & & & & 14 & & & & 14 & & \\
\hline 15 & & & & 14 & & & & 14 & & \\
\hline 17 & & & & 14 & & & & 14 & & \\
\hline 19 & & & & 2 & 12 & & & 14 & & \\
\hline 21 & & & & & 14 & & & 14 & & \\
\hline 23 & & & & & 13 & 1 & & 14 & & \\
\hline 25 & & & & & & 12 & & 12 & 4 令で 2 頭死亡 & \\
\hline 27 & & & & & & 12 & & 12 & & \\
\hline 29 & & & & & & 12 & & 12 & & \\
\hline 31 & & & & & & 6 & 6 & 12 & 第 1 回成虫発生 & \\
\hline 8.2 & & & & & & & 10 & 10 & 5 令で 2 頭死亡 & \\
\hline
\end{tabular}

（註）*印成虫は，第 3 表で羽化した第 1 回成虫が，そのまま越冬した個体.

第 1 回成虫のいずれかが第 6 表の卵塊A, B を産卵.

第 1 回成虫は全て1975，12，20までに死亡.

第 5 表 ツヤアオカメムシ第 2 世代奻虫の飼育結果（1974）

\begin{tabular}{|c|c|c|c|c|c|c|c|c|c|c|}
\hline \multirow{2}{*}{ 卵塊 } & \multirow{2}{*}{ 卵数 } & \multirow{2}{*}{ 調査月日 } & \multicolumn{3}{|c|}{ 幼 } & \multicolumn{2}{|l|}{ 虫 } & \multirow{2}{*}{ 成虫 } & \multirow{2}{*}{ 合計 } & \multirow{2}{*}{ 储 } \\
\hline & & & 1 令 & 2 令 & 3 令 & 4 令 & 5 令 & & & \\
\hline \multirow[t]{6}{*}{$\mathrm{A}$} & 14 & 8.19 & 14 & & & & & & 14 & 8.15～16に産卵 \\
\hline & & 8.29 & & & 14 & & & & 14 & \\
\hline & & 9.10 & & & 3 & 7 & & & 10 & \\
\hline & & 21 & & & & & 6 & 1 & 7 & 第 2 回成虫発生 \\
\hline & & 25 & & & & & 4 & 3 & 7 & \\
\hline & & 27 & & & & & & 7 & 7 & \\
\hline B & 14 & & & & & & & & & 8.17産卵, 未喂化 \\
\hline $\mathrm{C}$ & 14 & & & & & & & & & 8.17産卵, 未卵化 \\
\hline \multirow[t]{3}{*}{$\mathrm{D}$} & 14 & 8.29 & 14 & & & & & & 14 & 8.25産卵 \\
\hline & & 9. 2 & & 14 & & & & & 14 & \\
\hline & & 4 & & & & & & & & 2 令ですべて死亡 \\
\hline \multirow[t]{3}{*}{$\mathrm{E}$} & 14 & 9. 6 & 14 & & & & & & 14 & 9.1産卵 \\
\hline & & 10 & & 14 & & & & & 14 & \\
\hline & & 12 & & & & & & & & 2 令ですべて死亡 \\
\hline
\end{tabular}

（註）卵塊 $\mathrm{A} \sim \mathrm{E}$ は, すべて第 3 表の第 1 回成虫より採卵.

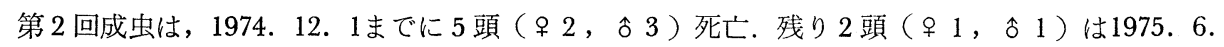
3〜6 および 21 死亡. 
第 6 表 ツヤアオカメムシ第 2 世代幼虫の飼育結果 (1975)

\begin{tabular}{|c|c|c|c|c|c|c|c|c|c|c|}
\hline \multirow{2}{*}{ 卵塊 } & \multirow{2}{*}{ 卵数 } & \multirow{2}{*}{ 調査月日 } & \multicolumn{3}{|c|}{ 幼 } & \multicolumn{2}{|l|}{ 虫 } & \multirow{2}{*}{ 成虫 } & \multirow{2}{*}{ 合計 } & \multirow{2}{*}{ 備 } \\
\hline & & & 1 令 & 2 令 & 3 令 & 4 令 & 5 令 & & & \\
\hline \multirow[t]{6}{*}{$\mathrm{A}$} & 14 & 8.22 & 14 & & & & & & 14 & 8, 18産卵。 \\
\hline & & 26 & & 14 & & & & & 14 & \\
\hline & & 28 & & 14 & & & & & 14 & \\
\hline & & 30 & & 14 & & & & & 14 & \\
\hline & & 9. 1 & & & 14 & & & & 14 & \\
\hline & & 3 & & & & & & & & 3 令ですべて死亡. \\
\hline B & 14 & & & & & & & & & 8.20産卵, 未卵孚化. \\
\hline
\end{tabular}

（註）卵塊 A，Bはすべて第 4 表の第 1 回成虫より採卵.

し，発育経過を観察した。

\section{結果および考察}

1974年，1957年のツヤアオカメムシの第 1 世代幼虫 の飼育結果は, 第 3 表, 第 4 表のとおりである。これ によれば, 第 1 世代の幼虫期間はほぼ25３0日であっ た.また，これらの第 1 回成虫の一部は産卵をして， 第 5 表，第 6 表のように第 2 世代の 発生が認められ た．第 2 世代の幼虫期間は，1974年の結果（第 5 表） では34〜40日で，第 1 世代より約10日ほど長くなった が，これには温度による影響も大きいと考えられる。 また, 室内飼育で発生した第 1 回成虫の一部と, 第 2 回成虫の一部はともに越冬を完了したので, 两世代と も越冬が可能と考えられる.

一方，誘殺個体中には越冬成虫は 8 月上旬で認めら れなくなるので，この間に産卵は終了しており，幼虫 期間を考慮すると第 1 回成虫は 8 月上旬〜 9 月に発生 しているものと考えられる。また, 寄主植物において, 6 月下旬〜 9 月下旬まで長期にわたって 1 令幼虫の発 生が認められることなど，早い時期に発生した第 1 回 成虫からは部分的に第 2 回成虫が発生していると考え られ, 年 $1 \sim 2$ 世代の発生が推察される. しかし, 野 外における両世代の明確な発生時期, 発生量は明らか にできなかった。

チャバネアオカメムシについては，沖縄では年 2 世 代，本州では年 1 世代といわれている1)が，世代の経

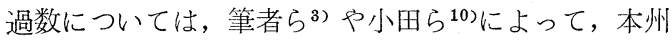
でも 2 世代の発生のあることが推察されている.

チャバネアオカメムシは，5月には畉巣が成熟して 産卵をする個体もあるが，越冬成虫の主な産卵期は， 分散活動が活発化し 誘殺数も多くなり（第 5 図）， ス ギ，ヒノキに 1 令幼虫の密度の高まる 6 月下旬から 8 月上旬ころまで（第7図）と考えられる.したがって
幼虫期間10,12)を考慮すると，7 月下旬〜 8 月下旬にわ たり第 1 回成虫が発生していると推察される。室内飼 育をした第 1 回成虫はまもなく産卵し，越冬をせずに 死亡することが観察された．また，野外では 9 月下旬 まで 1 令幼虫が認められた (第 7 図)。このようなこ とから, チャバネアオカメムシは, 年 2 世代の発生が あると推察される。しかし，野外における各世代の発 生時期, 発生量は, ツャアオカメムシ同様に明らかに できなかった。

\section{引用文 献}

1）長谷川 仁, 梅谷献二(1974) 植物防疫, 28(7): $279-286$.

2）池田二三高(1974)農林水産研究情報，41:22-23.

3）池田二三高, 福代和久（1975）昭和49年度落葉果 樹試験研究打合せ会議資料 (虫害).

4）川沢哲夫, 河村 満 (1975) カメムシ百種, 全国 農村教育協会, p. 301 .

5）KовAYASHI，T.（1956）四国昆虫学会報，4(8)： $123-126$.

6) 小林 尚 (1975) 第19回応動昆大会講要 : 416 .

7）宮原 実, 行徳直已 (1962) 九州病虫研報, 8 : 11-13.

8）宮原 実, 山田健一（1975）昭和49年度落葉果樹 試験研究打合せ会議資料 (虫害).

9) $308-309$.

10）小田道宏, 上住 泰 (1976) 同上：283-293.

11）山田健一, 宮原 実 (1974) 九州病虫研報, 20 : $53-56$.

12）山形農試 (1976) カメムシ類の生態および防除に 関する研究の現状と問題点, 農林水産技術会議事 務局, p. 353 . 